\title{
A PÁLYÁZAT MINT JELENSÉG A KÉSŐ HISTORIZÁLÓ ÉPÍTÉSZET KORÁBAN ${ }^{1}$
}

\author{
SZÉKELY MÁRTON* - MARÓTZY KATALIN** \\ *PhD-hallgató. BME Építészettörténeti és Mủemléki Tanszék, 1111 Budapest, Mủegyetem rkp. 3. K II. 82. \\ E-mail: szekely.marton86@gmail.com \\ **PhD, egyetemi adjunktus. BME Építészettörténeti és Műemléki Tanszék, \\ 1111 Budapest, Műegyetem rkp. 3. K II. 60. Tel.: (+36-1) 463-1330. E-mail: mkata@eptort.bme.hu
}

\begin{abstract}
Az építészeti tervpályázatok története Magyarországon a XIX. század közepén kezdődött, és az első világháborúig folyamatos fejlődést tapasztalhatunk. A kiegyezés környékének jelentős tervversenyeit korábban már kutatták, azonban a késő historizmus évtizedeiben megszaporodó pályázatok közül mindeddig csak néhányról született részletes elemzés. Tanulmányunk célja az Ybl Miklós halálától az I. világháborúig terjedő korszak pályázati eseményeinek összefoglalása, melyhez elsődleges forrásunk a korabeli szaksajtó volt. Az 1890-1920 közötti évek pályázati témájú sajtómegjelenéseinek összesítésével készült adatsorok alapján mutatjuk be a korszakbeli tendenciákat és a kiemelt figyelmet keltő pályázatok sorát. A XX. század első éveiben rohamosan fejlődő nyomdatechnikának köszönhetően nagy mennyiségü meg nem épült pályatervet ismerünk a korszakból, melyek - a megvalósult tervek mellett - tovább árnyalhatják ismereteinket a századforduló építészetéről. A hazai szakmai érdekképviselet úttörője, a Magyar Mérnök és Építész Egylet (1867-1944) müködése során mindvégig legfontosabb feladatai között tartotta számon a pályázatok ügyét, s a szervezet által jegyzett dokumentumok értékes, új adalékokkal szolgálhatnak a szaktörténet számára.
\end{abstract}

Kulcsszavak: historizmus, késő historizmus, tervpályázat, építészeti pályázat, építészettörténet, századforduló, XIX. század második fele, Magyar Mérnök és Építész Egylet

\section{BEVEZETÉS}

A tervpályázat eszmei célja, hogy a legfrappánsabb építészeti gondolat győzedelmeskedjen egy adott feladat megoldása során. Az építészeti tervpályázatok vitathatatlanul a szakma fontos, reprezentatív eseményei közé tartoznak, a versenyhelyzet különleges körülményeket teremt, jelentőségük így túlmutat a megvalósulást lehetövé tevő (engedélyezési, kiviteli, megvalósulási) terveken. A pályaművek a szakma és társadalom felé is reprezentatív céllal készülnek, egymással összevetve többet mondanak az utókor számára; nem pusztán egy-egy konkrét épület megvalósulásának kottái, hanem a mindenkori építészeti gondolkodás és tervezési módszertan hiteles lenyomatai az építészeti írás szövegei mellett. A pályázati dokumentumok különösen beszédesek az építészeti gondolkodás fejlődésének szempontjából, de a pályázatok történetének következetes feltárása ma még hiányzik a magyar építészet-

${ }^{1}$ A tanulmány a Bolyai János Kutatási Ösztöndíj támogatásával készült. 
történeti írásból. A szakmatörténet eme szelete arra is használható, hogy újfajta szempontrendszert adjon egyes építészeti korszakok behatóbb tanulmányozásához. A XIX. század építészetének tárgyalása hagyományosan stílustörténeti szempontú, többnyire még napjainkban is.

A kutatásunk fókuszában álló, a század végén és a századfordulón virágzó késő vagy más néven stíluskeverő historizmus sokáig erős kritikákat kapott. ${ }^{2} \mathrm{E}$ kritikák mind a megelőző, mind a következő korszakokhoz képest alacsonyabbra értékelték ezt az irányzatot, ezért a mai napig kevésbé kutatott korszaknak számít, bár az ezredforduló óta szaporodó irodalom egyre mélyebben feltárja értékeit. ${ }^{3}$ Úgy véljük, a Magyarországon széles körben éppen ebben a korszakban elterjedő pályázati jelenség beható vizsgálata új szempontokat kínál az 1880-as években kisarjadó, a második világháborúig túlélő stíluskorszak építészetének jobb megértéséhez.

\section{ELÖZMÉNYEK}

A nyugati világ építészetének történetét végigkísérte a tervezők és tervek versenyeztetése. Általában különleges helyzetben: reprezentatív építkezések során, illetve addig nem látott technikai kihívások megoldásának keresésekor fordult elő, hogy több alkotó egyéni válaszát összevetve, a legjobbnak gondolt koncepciót választották és annak szerzőjét bízták meg a megvalósítással. Már az ókortól a kora újkorig terjedő időszakból ismerünk tervversenyeket, ${ }^{4}$ de ezek még nem tekinthetők a modern kori pályázatok közvetlen előzményeinek. Noha a versenyzés és a pályamúvek összemérése már megjelenik, a modern pályázatok alapvetően polgári szemlélete teljességgel hiányzik, pusztán a megbízó igényeit próbálják kielégíteni. ${ }^{5}$ A korszerü pályázat ellenben intézményes keretek közt próbál lehetőséget teremteni az építész tervezők számára a nyílt versenyzésre.

A tervpályázat eme demokratikus ideája a felvilágosodás korában született meg, az első mai értelemben vett építészeti pályázatok a XVIII. század végi polgári forradalmak után jelentek meg. Az első nyílt nemzetközi pályázatokat a haladó országokban hirdették meg, ezek közt is élen járt az Egyesült Államok, ahol az új szövetségi

\footnotetext{
${ }^{2}$ A nemzeti formanyelv megalkotására törekvő irányzatokkal, majd a modernizmussal való összehasonlítás eredményeként. Fülep Lajos: Európai mủvészet és magyar müvészet. Nyugat 11 (1918) 6; Bierbauer Virgil: Két korszak mezsgyéjén. In: Az 50 éves Vállalkozók lapja. Jubileumi albuma 1879-1929. Szerk.: Lakatos Mihály. Budapest 1930. 115-121.

${ }^{3}$ Ennek tanúbizonysága a nemrég megjelent korszak-összefoglaló is: A magyar müvészet a 19. században. Szerk.: Sisa József. Osiris Kiadó, Budapest 2013.

${ }^{4}$ Például az athéni Parthenon vagy a firenzei dóm kupolája, de számos képzőművészeti verseny is megemlíthető előzményként.

${ }^{5}$ A firenzei dóm kupolájának esetében az építtetők csak azért hirdettek versenyt, mert az addig a megbízást birtokló mesterek között - a céheken belül - öröklött szaktudás nem volt elegendő az új léptékü probléma megoldására, tehát a verseny célja nem a legjobb építészeti megoldás tervezőjének megtalálása volt, hanem a kényszer szülte, miszerint a kérdést meg kell válaszolni, és akinek sikerül, az juthat a feladathoz szemben az addig megbízott mesterekkel.
} 
főváros legfőbb középületeire írtak ki nyílt tervpályázatot. A Fehér Házra és a Kapitóliumra 1792-ben kiúrt tervversenyek tekinthetőek az első sikeres, „modern” pályázatoknak. ${ }^{6}$ Ezt követően az 1800 -as évek elején a polgárosodott politikai berendezkedésủ országokban sorra írtak ki nyílt pályázatokat, kezdetben a legjelentősebb reprezentatív középületekre, majd egyre szélesebb körben. Az egyes országok szakmai érdekképviseleti szervei igyekeztek szabályozni az új jelenséget, az Egyesült Királyságban a Royal Institute of British Architects 1872-ben adta ki első pályázati szabályzatát, ${ }^{7}$ Franciaországban 1864-ben, ${ }^{8}$ Poroszországban 1867-ben, ${ }^{9}$ Bécsben 1874-ben, ${ }^{10}$ Svájcban 1878 -ban ${ }^{11}$ alkottak szabályzatot a tervversenyekre. ${ }^{12}$

Ha sorra vesszük a századhoz tartozó legjelentősebb nyílt, nemzetközi, pályázatokat - melyek nyomán meg is valósultak a tervezett épületek -, akkor elsőként a már említett Fehér házról és Kapitóliumról érdemes megemlékezni. Egy új ország, az Egyesült Államok, kormányzatának leendő jelképeit kívánta pályáztatással megterveztetni, ami egybevágott a fiatal állam demokratikus elköteleződésével. A puritán, klasszicista stílusú elnöki rezidenciát James Hoban, ${ }^{13}$ míg a Kongresszus palotáját William Thornton ${ }^{14}$ tervei alapján kezdték el építeni. ${ }^{15}$ Nem sokkal később Európa egyik első jelentős nemzetközi tervversenye a német klasszicizmus szellemében fogant Walhalla emlékmü 1817-es pályázata volt, melyet Leo von Klenze ${ }^{16}$ Duna-parti tájba jól illeszkedő terve nyert meg.

A század közepi gazdasági prosperitás nyomában a fejlett országokban előrehaladt a polgárosodás folyamata is, mely bázist jelentett a pályázati jelenség elfogadottá, sőt idővel elvárttá válásához. A kor egyik vezető hatalma - Nagy-Britannia Londonban új, reprezentatív parlament felépítéséröl döntött. 1835-ben pályázatot írtak ki a tervekre, melyet az Augustus Welby Northmore Pugin ${ }^{17}$ - Sir Charles Barry ${ }^{18}$ páros nyert, gótizáló romantikus tervével. E pályázat teret adott a viktoriánus korszak stíluseszméinek versenyéhez; a klasszikus formákat alkalmazókkal szemben álltak azok a romantikus felfogást valló építészek, akik a középkori erkölcsökhöz való visszatérést tartották üdvösnek, s ennek építészeti eszközét a gótizálásban lát-

${ }^{6}$ Architectural competitions 1792-today. Szerk.: Erik Mattie - Ceres De Jong. Benedikt Taschen, Köln 1994.

${ }^{7}$ Angela Mace: Architecture in manuscript, 1601-1996: A Guide to the British Library Manuscripts and Archives Collection. Mansell 1998. 267.

${ }^{8}$ Jeanne Laurent: Arts et pouvoirs en France de 1793 à 1981. Histoire d'une démission artistique. CIEREC, Saint-Étienne 1982. 69.

${ }^{9}$ Architectural competitions 1792-today, i. m. 13.

${ }^{10}$ Walter M. Chamostra: Wettbewerbsordnung Architektur. BIK-Verlags-Ges.m.b.H, Wien 2010. 7.

${ }^{11}$ Építö Ipar (a továbbiakban: ÉPIP) (1878) 103-104.

${ }^{12}$ A külföldi szabályzatokat az ÉPIP a magyar szakma számára publikálta is: (1878) 103; (1879) 298-299, 313-314, 336-337, az Österreichischer Ingenieur- und Architekten-Verein szabályzata: ÉPIP (1894) 192.

${ }^{13}$ James Hoban (1755-1831) ír származású amerikai építész.

${ }^{14}$ William Thornton (1759-1828) brit-amerikai tudós, festő, építész.

${ }^{15} \mathrm{Az}$ épületek hivatalosan 1800-ra készültek el. Architectural competitions 1792-today, i. m. 15.

${ }^{16}$ Leo von Klenze (1784-1864) müncheni építész.

${ }^{17}$ Augustus Welby Northmore Pugin (1812-1852) angol építész.

${ }^{18}$ Sir Charles Barry (1795-1860) angol építész. 
ták. Később, 1866-ban a legfelsőbb bíróság épületére is nyílt pályázatot hirdettek Londonban. Ekkor szintén gótizáló terv nyerte el a zsüri tetszését, az épület George Edmund Street ${ }^{19}$ tervei alapján valósult meg. ${ }^{20}$

A század közepén Európa két tekintélyes fővárosa, Párizs és Bécs is átfogó városrendezési munkálatokba kezdett: Bécsben az új körút: a Ring megtervezésére 1858ban nyílt, nemzetközi pályázatot hirdettek, Párizsban pedig Georges Eugène Haussmannt ${ }^{21}$ közvetlenül bízták meg az új, széles sugárutakra szervezett utcahálózat megtervezésével. Mindkét rendezési tervben kiemelt pozícióba került az operaház, melyre mindkét esetben nyílt pályázatot írtak ki. A Bécsi Udvari Operaház tervezését az August Sicard von Sicardsburg ${ }^{22}$ - Eduard van der Nül123 tervezöpáros nyerte el egy szikár stílustiszta neoreneszánsz tervvel. Párizsban többfordulós pályázatot rendeztek az operaházra, az első kör hét legjobbját hívva meg második fordulóra. Ezt végül az első fordulón ötödik helyezett Charles Garnier ${ }^{24}$ fölöttébb expreszszív terve nyerte meg, melynek burjánzó ornamentikáját a reneszánsz és barokk elemek dinamikus egyensúlya határozta meg, megteremtve az úgynevezett Garnierstílust.

Amszterdamban két jelentős pályázat is zajlott a korszakban. Az első az 1863-as Nemzeti Múzeum tervversenye volt, melynek eredményeként Petrus Josephus Hubertus Cuypers ${ }^{25}$ gótikus és reneszánsz elemeket vegyítő, historizáló terve valósult meg. ${ }^{26} \mathrm{Az}$ amszterdami tőzsdepalota 1884-es pályázatán Hendrik Petrus Berlage $^{27}$ progresszív terve nyert, mely - formanyelvét tekintve - a századfordulós tendenciák egyik elöfutárának is tekinthetö.

Az 1871-ben egyesült Németország fóvárosává váló Berlin egyik legfontosabb építészeti feladata az új szövetségi parlament épületének megtervezése volt, melyre a német állam 1872-ben nyílt nemzetközi tervpályázatot írt ki. A beérkezett 103 pályamü közül Ludwig Bohnstedt ${ }^{28}$ kapta az első díjat, de az építkezés elmaradt. ${ }^{29}$ Később, 1881-ben új pályázatot írtak ki a Reichstag épületére, ekkor már csak német építészek számára. A győztes - és megvalósult - terv szerzője Paul Wallot ${ }^{30}$ volt. ${ }^{31}$

${ }^{19}$ George Edmund Street (1824-1881) angol építész.

${ }^{20} \mathrm{Az}$ épületet 1882-ben avatták föl.

${ }^{21}$ Georges Eugène Haussmann (1809-1891) francia politikus.

${ }^{22}$ August Sicard von Sicardsburg (1813-1868) osztrák építész.

${ }^{23}$ Eduard van der Nüll (1812-1868) osztrák építész.

${ }^{24}$ Charles Garnier (1825-1898) francia építész.

${ }^{25}$ Petrus Josephus Hubertus Cuypers (1827-1921) holland építész.

${ }^{26} \mathrm{Az}$ épület 1885-ben nyílt meg.

${ }^{27}$ Hendrik Petrus Berlage (1856-1834) holland építész.

${ }^{28}$ Ludwig Bohnstedt (1822-1885) német építész.

${ }^{29} \mathrm{~A}$ pályázaton indult Steindl Imre is, díjazást vagy megvételt nem nyert, de pályaterve részben fennmaradt (Építészettörténeti Rajztár: 104023-104034). Steindl e pályázati munkájának összefüggéseiről bővebben: Székely Márton - Marótzy Katalin: Imre Steindl's Neo-Gothic approach in the Hungarian design competitions of the 1870's. Architektúra \& Urbanizmus (2016) 1-2. 66-77.

${ }^{30}$ Paul Wallot (1841-1912) német építész.

${ }^{31} \mathrm{~A}$ második világháborúban súlyosan sérült épületet Németország újraegyesítése után építették újjá, a rekonstrukcióra kiírt pályázaton győztes Norman Foster tervei szerint, kortárs üvegkupolával. 
Széles társadalmi rétegeket megmozgató események voltak ekkoriban a világkiállítások, melyek közül az 1889-es párizsi fő attrakciója, a később világhírüvé vált Eiffel-torony tervezését nyílt pályázat ${ }^{32}$ útján nyerte a névadó tervező: Gustave Eiffel. ${ }^{33}$ 1903-ban három nagy nemzetközi tervpályázat is lezajlott, és mindhárom egy elöremutató, a legfrissebb trendeknek megfelelő terv győzelmével zárult. Bécsben a Postatakarékpénztár épületének pályázatán Otto Wagner ${ }^{34}$ szecessziós terve, Stockholmban a városházáén Ragnar Östberg, ${ }^{35}$ Helsinkiben pedig a pályaudvarén Eliel Saarinen ${ }^{36}$ terve kapott első helyezést - és valósult meg.

A rövid kitekintést a hágai Békepalota 1905-ös tervpályázatával kell zárnunk, amely a XIX. századi historizmus utolsó nagyszabású seregszemléje volt. A korszak divatos áramlatainak megfelelő századfordulós stílusú tervek mellett premodern és különféle historizáló koncepciókkal is találkozhatunk. Érdekes módon egy kifejezetten konzervatív - neoreneszánsz stílusú - elképzelés valósult meg, szerzője LouisMarie Cordonnier ${ }^{37}$ volt.

A legfontosabb korabeli magyar építészeti szaklap - az Építési Ipar - évfolyamait átlapozva úgy tünhet, mintha itthon kevéssé foglalkoztak volna a nemzetközi pályázatokkal, hiszen csak szórványosan adtak tudósítást róluk. ${ }^{38}$ Figyelembe véve azonban, hogy a ma ismert, korabeli építészkönyvtárakban nemzetközi folyóiratok, pályázatokat bemutató kiadványok, nyertes terveket bemutató publikációk is szerepelnek, ${ }^{39}$ számolhatunk azzal, hogy a felsorolt nemzetközi eseményeket a szakma tájékozott része jól ismerhette.

\section{A MAGYARORSZÁGI ÉPÍTÉSZETI PÁLYÁZATOK 1890-IG}

Magyarország történetének első - mind ez ideig ismert - jelentős tervpályázata az 1844-es Országház-pályázat volt. A reformkor liberális légköre sarkallta a döntéshozókat nyílt nemzetközi pályázat kiírására - az akkor már szaporodó külföldi példákat követve. A határidőre összesen 41 pályamü érkezett be - számos külföldről -, ami akkoriban igen figyelemreméltónak számított. ${ }^{40}$ A tervek bírálata sosem történt meg, azt az 1847/48-as országgyúlés kezdte volna meg, de a márciusi forradalom miatt ez

\footnotetext{
${ }^{32}$ A pályázatot Eiffel régebbi ötlete alapján írták ki, megelőző tanulmányterveit is figyelembe véve, így nem meglepő, hogy ő nyerte el a megbízást.

${ }^{33}$ Gustave Eiffel (1832-1923) francia építész.

${ }^{34}$ Otto Wagner (1841-1918) osztrák építész.

${ }^{35}$ Ragnar Östberg (1866-1945) svéd építész.

${ }^{36}$ Eliel Saarinen (1873-1950) finn építész.

${ }^{37}$ Louis-Marie Cordonnier (1854-1940) francia építész.

${ }^{38}$ Például a Kaliforniai Egyetem nagyszabású tervpályázatának ismertetése, melyben látványosan kihangsúlyozták a lebonyolítás mintaszerüségét. ÉPIP (1900) 155, 159.

${ }^{39}$ Marótzy Katalin: Wéber Antal könyvtára. Épités - Építészettudomány 34 (2006) 1-2. 87-112; Halmos Károly - Sebők Richárd: Hild József könyvtára: Rövid ismertetés és konkordancia. Tanulmányok Budapest Múltjából 38 (2013) 57-115.

${ }^{40}$ Összehasonlításképp: a londoni parlament tíz évvel korábbi pályázatára 98 terv érkezett be.
} 
elmaradt. A mai Erzsébet térre készült országháztervek nagy része elveszett, néhány tervlapot leszámítva csak leírások maradtak fent. ${ }^{41}$ Az ország politikai helyzetéböl adódóan a pályázattörténet is csak évtizedek elteltével folytatódott.

A pályázati eljárás térnyerésének kezdeti példája a debreceni színház esete. ${ }^{42}$ 1857-ben a város Ybl Miklóst ${ }^{43}$ bízta meg állandó színházépület tervezésével, majd 1860-ban másik helyszínre rendeltek terveket ugyancsak Ybltől. A végleges tervek készítése közben azonban a Színházi Bizottmány mégis pályázat kiírásáról határozott, melyre Ybl mellett Szkalnitzky Antalt ${ }^{44}$ is meghívták. Ybl méltatlannak érezve a helyzetet, egyéb elfoglaltságaira hivatkozva visszalépett; így végül Szkalnitzky romantikus stílusú terve valósult meg. ${ }^{45}$

A befejezetlen Országház-pályázat után majdnem két évtized elteltével a Magyar Tudományos Akadémia 1861-es pályázata meghívásos volt, ${ }^{46}$ jelentős sajtóvisszhangja és építészeti jelentősége miatt különösen fontos a magyar pályázattörténetben. Erre első körben Ybl Miklóst és Henszlmann Imrét ${ }^{47}$ hívták meg, de Szkalnitzky Antal is beadott egy pályamüvet. Henszlmann volt a vezetője annak a befolyásos körnek, ami gótizáló épület mellett érvelt, ezen stílus eszmeiségét méltóbbnak találván a reprezentatív székházhoz. Ybl megígérte Henszlmannak, hogy gótizáló tervet készít, de nem így tett: neoreneszánsz tervet adott be, melyet másnap visszavont. Az első kör eredményével elégedetlen építési bizottság új pályázatot írt ki, melyre meghívtak két neves külföldi építészt: Friedrich August Stülert ${ }^{48}$ és Leo von Klenzét. Stüler neoreneszánsz terve nyerte az első díjat. ${ }^{49}$

Az 1844-ben elhamvadt ügyet folytatva 1861-ben a királyi palotában és a Nemzeti Múzeumban összeülő országgyülés egyik első intézkedésként meghívásos pályázatot hirdetett ideiglenes országgyülési épület terveire. E felhívásra Ybl Miklós, Mettelka, Ganz Ábrahám, ${ }^{50}$ Kauser Lipót ${ }^{51}$ és Wieser Ferenc ${ }^{52}$ nyújtottak be terveket és költségvetést. A kiírás nem kötötte ki a helyszínt, sem az épület formáját, így a

\footnotetext{
${ }^{41}$ A pályázatról és a tervek utóéletéről bővebben: Komárik Dénes: Az 1844-es Pesti Országháza tervpályázat. Tanulmányok Budapest Múltjából 19 (1972) 251-281; Bibó István: Pollack Mihály Országháza-terve. Müvészettörténeti Értesitő 22 (1973) 22-36; Az ország háza: Buda-Pesti Országháza-tervek 1784-1884. Szerk.: Verő Mária - Gábor Eszter. Szépmüvészeti Múzeum, Budapest 2000.

${ }^{42}$ Természetesen többször előfordult, hogy meghívásos jelleggel több tervezőt is felkértek elképzeléseik bemutatására, a korai időszakban gyakran részletes tervezési kiírás nélkül.

${ }^{43}$ Ybl Miklós (1814-1891) magyar építész.

${ }^{44}$ Szkalnitzky Antal (1836-1878) magyar építész.

${ }^{45}$ Az épület 1865-ben nyílt meg, a történetéről részletesebben: Sisa József: Szkalnitzky Antal és Ybl Miklós - két építész pályafutásának kapcsolódásai. In: Ybl Miklós építész 1814-1891. Szerk.: Kemény Mária Farbaky Péter. Budapesti Történeti Múzeum, Budapest 1991. 39-45.

${ }^{46}$ A pályázat és az épület történetéröl részletesen: Kemény Mária: A Magyar Tudományos Akadémia palotája. Osiris Kiadó, Budapest 2015.

${ }^{47}$ Henszlmann Imre (1813-1888) magyar művészettörténész, régész.

${ }^{48}$ Friedrich August Stüler (1800-1865) berlini építész.

${ }^{49} \mathrm{Az}$ épület 1865-re készült el.

${ }^{50}$ Ganz Ábrahám (1815-1867) magyar iparmágnás.

${ }^{51}$ Kauser Lipót (1818-1877) magyar építész.

${ }^{52}$ Wieser Ferenc (1812-1869) magyar építész.
} 
pályázók maguk választhattak az építési bizottság által megvizsgált helyszínek, illetve különböző szerkezeti megoldások ${ }^{53}$ közül. Ybl három, Wieser két tervet is beadott, végül Lónyay Menyhért miniszterelnö ${ }^{54}$ Wieser téglaszerkezetü tervét hagyta jóvá. Az építkezéshez akkor hozzá sem kezdtek, az 1865-ben összeülő országgyülés által felállított építési bizottság új meghívásos tervversenyt hirdetett ki, meghívva Ybl Miklóst, Diescher Józsefet, ${ }^{55}$ Szkalnitzky Antalt és Wieser Ferencet. ${ }^{56}$ Ybl tervét fogadták el kivitelre, mely rövid idő alatt ${ }^{57}$ el is készült a Sándor utcában, a Nemzeti Múzeum $^{58}$ tőszomszédságában.

A XIX. század 70-es éveiig Magyarországon viszonylag kevés pályázattal találkozunk, legtöbbször meghívásos tervversenyekkel, a kiírások és a lebonyolítás sokszor ötletszerünek tünnek. A kiegyezést követö gazdasági konjunktúra és egyre növekvő volumenú építési tevékenység azonban kedvezett a pályázatok terjedésének és így az eljárás kimunkálásának is. Az építészszakma első, modern értelemben vett érdekképviseleti szerve Magyarországon - mely, mint látni fogjuk, a pályázati rendszer aktív támogatója lett - az 1867-ben alapított Magyar Mérnök Egyesület volt. Az Egyesület 1872-ben vette fel a Magyar Mérnök- és Építész Egylet (MMÉE) nevet, és ellátta a mai kamarai feladatokat egészen 1944-ig. Kezdettől fogva fö céljai között szerepelt a pályázatok ügyének képviselete, évente saját egyleti pályázatokat hirdettek, tagjai gyakran vettek részt a bírálatokban. Hivatalos közlönyük, illetve mellékletei, a hazai építészeti szaksajtó történetének hajnalán úttörő jelentőségüek voltak. ${ }^{59}$

Első, pályázatokat képviselő lépésüket 1872-ben tették meg, amikor az új müegyetemi épület leendő tervezőjének kiválasztása kapcsán Feszty Adolf ${ }^{60}$ indítványozta, hogy az MMÉE intézzen felhívást a vallás- és közoktatásügyi miniszterhez annak érdekében, hogy jelentősebb építkezéseknél, a korábbi szokásokkal szakítva, ne direkt megbízás során nyerjék el a munkákat az építészek, hanem legalább részlegesen vezessék be a nyílt pályázati rendszert. Ez is mutatja, hogy a nagyobb megbízásokat ekkor még többnyire közvetlenül kapták az építészek, ami a fiatal - jellemzően nyugat-európai tanulmányi tapasztalattal rendelkező - szakemberek tiltakozását és követeléseik megfogalmazását váltotta ki. A javaslat hosszas vitája során a támogatók ${ }^{61}$ a fiatal tehetségekre ható előnyöket emelték ki, míg ellenzői a tekintélyes szakmabeliek pozícióit féltve, azok esetleges, a pályázati versenyzéstől való

${ }^{53}$ A pályaművek között találunk fa-, vas- és téglaszerkezettel operáló tervet.

${ }^{54}$ Lónyay Menyhért (1822-1884) magyar politikus, Magyarország miniszterelnöke 1871-től 1872-ig.

${ }^{55}$ Diescher József (1811-1874) magyar építész.

${ }^{56}$ Pereházy Károly: Régi pesti képviselőház. Tanulmányok Budapest Múltjából 15 (1963) 489-510.

${ }^{57} 1865$ szeptemberében kezdték az építkezést, 1866 áprilisában pedig már használatba is vette az Országgyülés a kész épületet.

${ }^{58} \mathrm{~A}$ felsőház itt ülésezett a Múzeum dísztermében.

${ }^{59}$ Magyar Mérnök és Épitész Egylet Közlönye (a továbbiakban: MMÉEK), megjelent 1867-1944 között (1872-ig Magyar Mérnök Egylet Közlönye címen).

${ }^{60}$ Feszty Adolf (1846-1900) magyar építész, feltaláló, országgyűlési képviselő. 1882-ben az ő terve nyert a Foncière Biztosító Intézet bérházának nyílt tervpályázatán. A pályázatról bővebben: Székely Márton - Marótzy Katalin: Design Competition for the Fonciére Palace, Andrássy Avenue, Budapest - A Pivotal Moment. Periodica Polytechnika Architecture 46 (2015) 1. 29-37.

${ }^{61}$ Ney Béla és Weber Antal támogatták az indítványt. MMÉEK (1872) 172. 
elzárkózásával érveltek. ${ }^{62}$ Végül az Egyletnek nem sikerült egyértelmüen támogató határozatot elfogadnia a szavazáson, de a felhívást elküldték az illetékes miniszternek. Bár a javaslatnak közvetlen hatása ekkor még nem volt, ez az első érdekképviseleti lépése annak a folyamatnak, mely a századfordulót jellemző - már jóval fejlettebb - pályázati kultúrához vezetett.

Néhány kevésbé jelentős épület hazai tervpályázata után fordulópontot jelentett, hogy az Operaház tervezésére 1873-ban nemzetközi, meghívásos pályázatot írtak ki. A kiírás konkrétan nevesítette az elvárt stílust: az itáliai ihletésü neoreneszánszt. Hat építészt hívtak meg: Ybl Miklóst, Steindl Imrét, ${ }^{63}$ Szkalnitzky Antalt Magyarországról, Linzbauer Istvánt, ${ }^{64}$ valamint a Ferdinand Fellner ${ }^{65}$ és Hermann Helmer ${ }^{66}$ párost Ausztriából, Ludwig Bohnstedtet pedig Németországból. A megbízást szinte egyhangú, 7:1-es szavazati aránnyal Ybl nyerte. A pályatervet Ybl később többször is módosította, az épület 1884-ben készült el. ${ }^{67}$ Ettől kezdve a pályáztatás fokozatos terjedését látjuk, a folyamat csúcspontja a korszakban az állandó országház ügye. ${ }^{68}$ Az 1882-ben született kiírásra, mely nyílt és nemzetközi versenyt kívánt, ${ }^{69}$ tizenkilenc ${ }^{70}$ pályamunka érkezett be 1883 áprilisára. Az építési bizottság négy első díjat osztott ki, melyek közül végül Steindl Imre pályatervének megépítését szavazta meg a testület. ${ }^{71}$ E négy elsődíjas terv közül csak Steindlé volt neogótikus stílusú, ${ }^{72}$ a másik három klasszikus, antik-reneszánsz formákból építkezett. ${ }^{73} E$ pályázat jelentősége túlmutat önmagán; nem pusztán az ország - azóta is - legfontosabb épületének megjelenését döntötte el, hanem minden addiginál reprezentatívabb volt a korszak építészetét tekintve, és stílustörténetileg is meghatározó állomásnak tekinthetjük a korai és kései historizmus tervversenyei között a sorban. ${ }^{74}$

\footnotetext{
${ }^{62}$ A szakmában ez a szituáció azóta is számos alkalommal feltünik, az évtizedek múlásával a korábban pályázatokat támogatókat gyakran találjuk a közvetlen megbízásokat preferálók között. Mindenképpen érdemes megjegyezni, hogy a pró és kontra érvek sem változtak sokat másfél század alatt.

${ }^{63}$ Steindl Imre (1839-1902) magyar építész.

${ }^{64}$ Linzbauer István (1838-1880) magyar építész.

${ }^{65}$ Ferdinand Fellner (1847-1916) osztrák építész.

${ }^{66}$ Hermann Helmer (1849-1919) osztrák építész.

${ }^{67}$ Borsa Miklós - Tolnay Pál: Az ismeretlen Operaház. Műszaki Könyvkiadó, Budapest 1984.

${ }^{68}$ Egry Margit: Az Országház. Képzőművészeti Alap Kiadóvállalata, Budapest 1956; Az ország háza: BudaPesti Országháza-tervek 1784-1884. Szerk.: Verő Mária - Gábor Eszter. Szépművészeti Múzeum, Budapest 2000; Csorba László: Az Országház. Képzőmüvészeti Kiadó, Budapest 2001; Tihanyi Bence: Az Országház. Magyar Könyvklub, Budapest 2001; Sisa József: Az Országház: történelmi séta. Corvina Kiadó, Budapest 2013.

${ }^{69}$ Sisa József: Steindl Imre. Holnap Kiadó, Budapest 2005. 106.

${ }^{70}$ Magyarország épitészetének története. Szerk.: Sisa József - Dora Wiebenson. Vince Kiadó, Budapest 1998. 229.

${ }^{71}$ Sisa József: Steindl Imre, i. m. 107.

${ }^{72}$ Ekkor ünnepelte Magyarország az államalapítás 1000 éves évfordulóját, a kortársak egy része a nemzet történelmének legdicsőségesebb korszakaként tekintett a késő középkorra, a gótika korára. Ezen befolyásos körök akarata érvényesült az elbírálás folyamata során.

${ }^{73}$ A másik három elsődíjas terv szerzői: Hauszmann Alajos, Otto Wagner és a Schickedanz Albert - Freund Vilmos páros voltak.

${ }^{74}$ Sisa József: Steindl Imre, i. m. 108-109.
} 
A késő historizmus részletes, pályázati szempontú tárgyalását 1891-től kezdjük. Ybl Miklós halálának éve több szempontból is korszakhatárnak tekinthető. Egyrészt szimbolikus okokból, Ybl a stílustiszta historizmus legbefolyásosabb hazai képviselője volt, aki tekintélyének köszönhetően a XIX. század 80-as éveire a szakmai közélet meghatározó, már-már egyeduralkodó egyéniségévé vált. Fontos szakmai tisztségeket is betöltött, ő volt a MMÉE Építészeti Szakosztályának elnöke, aktív szerepet vállalt a pályázatok előkészítésében és bírálásában is, a jelentősebb pályázati események szinte mindegyikére volt valamiféle befolyása. Halála után különféle pozícióin többen osztoztak, nem egy személy lépett a helyébe, így az 1890-es évektől a hazai építészeti közéletet nagytekintélyü építészek ${ }^{75}$ egyenrangú fellépése határozta meg. Ez a váltás egy stíluskorszakváltás időszakával, a stíluskeverő historizmus elterjedésével is egybeesett. Míg a tanulmány tárgyát képező korszak kezdő dátuma tehát 1891, végét 1920-ban határoztuk meg. Az első világháború és az azt követő gazdasági összeomlás miatt tíz évre gyakorlatilag leállt az építőipar Magyarországon, egyértelmüen véget vetve egy periódusnak.

\section{A PÁLYÁZATI KULTÚRA FEJLŐDÉSE MAGYARORSZÁGON 1891-TÖL 1920-IG}

A szakmai érdekképviseleti szervek kulcsszerepet játszottak a pályázatok hazai meghonosodásának folyamatában, ezért ki kell emelnünk néhány momentumot az intézmény és az általa koordinált szaksajtó történetéből. Magyarországon a kiegyezés utáni megalakulásától kezdve a már említett MMÉE története szorosan összekapcsolódik a pályázati kultúra és intézményrendszer fejlődésével, a tervversenyek ügyét következetesen elsőként az Egylet igyekezett képviselni Magyarországon. Már a megalakulás utáni második évben kidolgozták az első pályázati szabályzatot, ${ }^{76}$ de az 1890-es évekbeli publicisztikák a két évtizeddel korábbi viszonyokra visszatekintve azt mutatják, ${ }^{77}$ hogy a gyakorlatban az építtetők ezzel még kisebb mértékben éltek, mint azt az Egylet elvárta volna. ${ }^{78} \mathrm{Az}$ Egylet a pályázatok lebonyolításában is aktívan részt vett, leggyakrabban tagokat küldtek a bíráló bizottságokba, de sokszor kifejezetten az Egyletet kérték fel bírálatra. Ekkor bizottságot állítottak fel saját tagjaikból, vagy külső személyeket is bevonva. Bizonyos esetekben magát az Egyletet

\footnotetext{
${ }^{75}$ Steindl Imre, Hauszmann Alajos, Alpár Ignác, Lechner Ödön, Schulek Frigyes, Czigler Győző.

${ }^{76} \mathrm{~A}$ pályázati kérés folyamatosan az Egylet napirendjén volt, saját, belső pályázati szabályzatuk 1878-ban jelent meg - ÉPIP (1878) 48 -, első javaslatuk az általános szabályozásra 1879-ben született: ÉPIP (1879) $305-306$.

${ }^{77}$ Sterk János: Építőművészeti tervpályázatok. ÉPIP (1894) 257; Bauer Henrik: Építészeti versenyek. MMÉEK (1891) 52.

${ }^{78}$ A korai időszakban az ügy szószólói az említett Feszty Adolf mellett Pártos Gyula, Ney Béla, Schwarczel Sándor és Kiss István voltak.
} 
kérték fel tervezésre ${ }^{79}$ vagy tervező ajánlására, ilyenkor természetesen inkább a nyílt pályázatot javasolták az építtetőknek, akik az esetek többségében meg is fogadták e tanácsot. ${ }^{80}$ Készséggel segítettek már a pályázati kiírások elkészítésében is, ha ilyen kérés érkezett; de gyakoribb eset volt, hogy a sikertelen pályázat után kértek tanácsot a megrendelők a kiírás korrekciójára, ami így számos esetben sikeres pályázatot eredményezett. ${ }^{81}$ Nem volt azonban mindig szükség az építtető megkeresésére: az Egylet néhány rendkívüli esetben maga szólította fel módosításra a kírókat - méltánytalannak ítélve a kiírás egy vagy több paraméterét. ${ }^{82}$ Méltatták a sikeres pályázatok eredményét, ${ }^{83}$ az Egylet saját székházában többször teret biztosított ${ }^{84}$ a pályamüvekböl nyíló kiállításoknak is.

A pályázatok ügyének előlendítése céljából már 1877-től kezdve az MMÉE évente egyleti pályázatokat írt ki. A kírások témája igyekezett egyrészt a fiatal, referenciákkal és kapcsolati tőkével még nem rendelkező tehetséges építészeknek teret adni a kibontakozásra; másfelől úttörőként kívánt fellépni a legaktuálisabb szakmai kérdések megoldásában. Ezeken a pályázatokon csak tagok indulhattak. Kírásuk, elbírálásuk és díjazásuk lebonyolításában az Egylet igyekezett mintaszerüen eljárni, így ezen pályázatok formája legalább olyan tanulságos volt, mint a tartalmuk. ${ }^{85} 1882$-től már minden évben több belső pályázatot is meghirdettek, külön kis- és nagypályázatot, melyek - nevükböl adódóan is - a feladat léptéke szerint különültek el. 1891-töl évente „Ybl-pályázat”-ot is hirdettek az elhunyt mester emlékére, ez mindig valamilyen különleges feladatot, gyakran emléktárgy tervezését foglalta magában. Az építőipar teljesítményének - különféle okokból történő - hullámzása több válságidőszakot eredményezett a korszakban, ez új jelentőséggel ruházta fel az egyleti pályázatokat. Megrendelések híján így - legalább részben - feladatot tudott adni az építészeknek, és mozgásban tartotta a szakmai közéletet is. Ilyen periódus volt a századforduló drasztikus építőipari visszaesése (1899-1903), és ilyen funkciót töltöttek be az Egylet tervversenyei a válságos 1920-as években. A hagyomány egészen Magyarország második világháborús összeomlásáig tartott, az MMÉE utolsó egyleti pályázatát 1944-ben hirdette meg.

Sokatmondóak az egyleti pályázatok szabályzatai, melyek többszöri módosítása és kihirdetése végigkísérte az Egylet korszakbéli müködését. 1891 után elöször

\footnotetext{
${ }^{79} \mathrm{Pl}$. a Pécsi Kereskedelmi és Iparkamara épületére 1892-ben. Rosch Gábor: Alpár Ignác épitészete. Enciklopédia Kiadó, Budapest 2005. 42-55.

${ }^{80}$ Legalábbis az általunk a sajtóból ismert esetek szemrevétele alapján elmondható. Pl. a kecskeméti takarékpénztár 1905-ben.

${ }^{81}$ Pl. a balmazújvárosi zsinagóga 1903-as pályázata. Vállalkozók Lapja (a továbbiakban: VL) (1903) 5. 7.

${ }^{82} \mathrm{Pl}$. a debreceni vármegyeház díszterem-átalakításának 1901-es pályázata. $V L$ (1901) 10. 8.

${ }^{83}$ Legnagyobb terjedelemben az ÉPIP és a $V L$ foglalkozott pályázatrovataiban és gyakran vezércikkeiben is a témával.

${ }^{84}$ Pl. 1892-ben kiállították a New York palota meghívásos tervpályázatának pályamúveit - ÉPIP (1892) 34 -, illetve 1901-ben az Osztrák-Magyar Bank pályázatának terveit: ÉPIP (1901) 114.

${ }^{85}$ Marótzy Katalin: Ybl Miklós és az építészeti közélet - pályázatok a Magyar Mérnök- és Építészegyletben. Ars Hungarica 40 (2014) 4. 489-496.
} 
1896-ban hirdették ki az új, kifejezetten egyleti pályázatokra vonatkozó szabályzatot, majd 1907-ben újra megjelenik a „Pályázatok eljárási szabályzata”. ${ }^{86}$ Végül a korszakbéli utolsó - kereskedelmi miniszterhez intézett - felterjesztés után nem sokkal, 1912-ben publikálták újfent az egyleti tervversenyek szabályzatait - külön cikkben a kis- és a nagy-, illetve Ybl-pályázatokra vonatkozó előírást. ${ }^{87}$ E szabályzatokat végigtekintve azt figyelhetjük meg, hogy a konkrét utasításokban nem volt lényegi változás, a szövegek célja inkább az volt, hogy emlékeztessen a legfontosabb formai körülmények ideális meghatározására. A pályázati szabályzatok szövegei alapvetően mindig tömörek és világosak voltak, néhány alapvető kulcskérdés tisztázásán túl nem kívánták túlzottan megkötni a résztvevők kezét. ${ }^{88}$

1891-ben, Ybl halála után nem sokkal az Egylet felterjesztést tett a tervezőpályázatok ügyében a belügyminiszterhez, melyben általános jellegü kívánalmakat fogalmaztak meg. ${ }^{89}$ Az Egylet a pályázat intézményének köztudatba emeléséhez újabb eszközéül használhatta a beadványokat. Arra utal a szöveg, hogy a tervpályázatok számát már bíztatónak találják, de a lebonyolításuk mikéntje még sokszor nem ideális. A kiírók éppen a gondolatok szabad versengésének szabnak gátat azáltal, hogy nagy léptékü terveket és részletes költségvetést kérnek. Fontosnak tartották, hogy ne lehessen 1:200-as léptéknél részletesebb rajzokat kérni, és csak köbtartalom alapján számolt, egyszerü költségbecslés legyen beadandó. ${ }^{90}$ A következő egyleti felterjesztést 1902-ben nyújtották be a kormányhoz, majd 1904-ben a vallás- és közoktatásügyi miniszterhez. 1908-ban kereskedelmi miniszteri rendeletben ${ }^{91}$ szabályozták az építészeti tervpályázati eljárásokat, e rendeletet 1909-ben módosították. ${ }^{92} 1912$ ben az Egylet újra felterjesztéssel élt, akkor már a kereskedelmi miniszterhez, melyből látható, hogy a szakmai szervezet igyekezett a kormányzaton belül megtalálni ügyének aktív pártfogóját, miután a belügyi, illetve a kulturális tárcáknál nem jártak sikerrel. E felterjesztés az 1908-as rendeletre hivatkozott, miszerint annak pozitív hatása, bár érezhető, a helyzetet javíthatná, ha - legalább a közigazgatási szféra által kiírt pályázatoknál - szigorúbban betartatnák a szabályzó rendeletet. ${ }^{93}$ A felterjesztés

\footnotetext{
${ }^{86}$ Ebben leszögezték az olyan alapvetéseket, mint a már említett 1:200-as lépték. Meghatározták, mit kell tartalmaznia egy jó kírásnak (program, határidő, díjazás, zsüritagok, eredményhirdetés határideje és a nyertes megbízatására vonatkozó ígéret). Felsorolták, mikor milyen munkarészek kérhetőek be (pl. megszabták, milyen esetekben indokolt távlati vagy madártávlati kép elöírása). Megfogalmazták, milyen okokból kell valakit kizárni (például nemcsak ha elöírt munkarész hiányzott, hanem ha a pályázó a kiírásban nem szereplő munkarészt adott be!) - ÉPIP (1907) 301.

${ }^{87}$ MMÉEK (1912) 216, 790, 791.

${ }^{88} \mathrm{Az}$ ebben való hitükről tanúskodhat a kritika is, amivel az Osztrák Mérnök- és Építészegylet pályázati rendjét tartják túlszabályozottnak. ÉPIP (1894) 192.

${ }^{89}$ ÉPIP (1891) 157.

${ }^{90}$ Bauer Henrik: Építészeti versenyek. MMÉEK (1891) 52.

${ }_{91}^{179049 / 1908 . ~ s z . ~ k e r e s k e d e l m i ~ m i n i s z t e r i ~ r e n d e l e t . ~}$

${ }^{92} \mathrm{Az}$ 1908-as rendelet 12020. számú átirata. Magyar Mérnök és Épitész Egylet Heti Értesitője (a továbbiakban: MMÉEHÉ) (1912) 351.

${ }^{93}$ MMÉEK (1912) 215.
} 
nem volt hasztalan: a miniszter az Egyletnek küldött válaszában közölte, körrendeletet hirdetett ki a közigazgatásban, amiben a szabályzat minden pontjának betartására szólítja fel az illetékeseket. ${ }^{94}$

A pályázatokról a korabeli szaksajtó tájékoztatott, a Magyar Mérnök és Épitész Egylet Közlönye, illetve mellékletei ${ }^{95}$ mellett az első kifejezetten építészeti tárgyú szaklapok, melyek az 1870-es évek közepén indultak, elsőként a német nyelvü Bauzeitung für Ungarn,$^{96}$ majd az 1877-ben alapított Épitési Ipar ${ }^{97}$ jelent meg a palettán, mely rendelkezett külön tervpályázati rovattal, ${ }^{98}$ ami igen széles körü képet ad számunkra a korszakban kiírt pályázatokról. Szinte bizonyos, hogy a hazai nyílt ${ }^{99}$ pályázatok túlnyomó többsége szerepel ezekben a sajtóorgánumokban. Ezenkívül rendszeres tudósítást is adtak a pályázati eseményekről - a korszakban előre haladva egyre bővebben illusztrálva, ${ }^{100}$ és szerkesztőségi tárcacikkekben foglalkoztak a tervversenyek általános problémáival is. ${ }^{101} \mathrm{Az}$ Egylethez közel álló lapokon kívül további hasznos forrást jelent az áttekintéshez a Vállalkozók Lapja ${ }^{102}$ illetve a Vállalkozók Közlönye is. ${ }^{103}$ Szemléletes számunkra a rövid életünek bizonyult Magyar Épitöomüvészeti Pályázatok ${ }^{104}$ címủ kiadvány, mely 1894-1995 folyamán mindössze hat füzettel jelent meg, deklarált célja volt iránymutatást adni a pályáztatóknak és pályázóknak egyaránt. Az 1902-ben alakult Magyar Építőművészek Szövetsége ${ }^{105}$ (MÉSZ) mủködésének második évétől Magyar Pályázatok címmel jelentetett meg folyóiratot. Már a címe is mutatja, hogy a periodika legfontosabb célja a tervpályázatokról való tudósítás volt, ami nem változott 1907 után sem, mikor a lap felvette a Magyar Épitőmüvészet címet, s e néven jelent meg egészen 1944-ig.

${ }^{94}$ MMÉEK (1912) 351.

${ }^{95} \mathrm{Az}$ MMÉEHÉ a Közlöny mellékleteként jelent meg 1882-1910 között.

${ }^{96}$ 1876-tól 1896-ig megjelenő német nyelvű, főleg budapesti épületekkel foglalkozó építészeti szaklap.

${ }^{97}$ 1887-től Épitö Ipar, 1914-től pedig Építö Ipar, Építő Müvészet címen jelent meg 1932-ig.

${ }^{98}$ A korszak elején a pályázat szó alatt alapvetően álláshirdetést értettek, így a külön tervpályázat, illetve tervezö- vagy tervezési pályázat kifejezéseket használták hivatalosan az építészeti tervverseny megjelölésére.

${ }^{99} \mathrm{~A}$ meghívásos pályázatokról jóval kevesebb információ áll rendelkezésünkre, mivel ezeket nem kellett meghirdetni nyilvánosan, és eredményükről is csak ritkán tudósítottak, a magánépíttetők ez irányú tartózkodása a nyilvánosságtól a korszakban érzékelhetően csökkent.

${ }^{100}$ Nemcsak az érdeklődés, hanem a nyomdatechnika fejlődésével is párhuzamosan.

${ }^{101}$ Ezeket leggyakrabban a fószerkesztő Ney Béla jegyezte.

${ }^{102}$ 1879-től 1932-ig megjelent építészeti, építőipari hetilap, alcíme szerint a „Szállítási és építési vállalkozók félhivatalos közlönye" volt. 1901-ben föszerkesztője Komor Marcell lett. Mellékleteként indult a később önállósult Tér és Forma címü lap.

${ }^{103}$ 1895-től 1925-ig jelent meg, alcímében magát az építő-, szállító- és vállalkozó ágak szaklapjaként megjelölve.

${ }^{104}$ Szerkesztette: Sterk János.

${ }^{105}$ Baku Eszter - Csernus Éva: A Magyar Építőművészek Szövetségének története 1902-1948 között. Épités - Épitészettudomány 40 (2012) 1. 113-134. 


\subsection{KIÍRÓK, ÉPÍTTETÖK}

A pályázat során a kiíró szükségszerủen a folyamat domináns szereplője. Alapvetően két csoportra oszthatjuk a tervversenyeket a kírók szerint: magán- és középítési pályázatok. Magyarországon a XIX. század végén a kiírt, ismert pályázatok alig tizede vonatkozott magánépületre, ezek általában pénzintézetek iroda- és bérházai voltak, a tervversenyek túlnyomó többségét állami középületekre hirdették meg. Ezekben az esetekben az építtető - aki a pályázat kiírását jegyezte - maga az állam; az illetékes szakminisztérium, városi tanács, vármegye vezetősége, polgármester, vagy épp a megyei ispán volt. A jelentősebb közberuházásokat szinte mindig építési bizottság felállításával kezdték, ennek feladata volt a pályázat lebonyolításának koordinálása: a program összeállítása, a díjazás megállapítása, a kiírás meghirdetése, a bíráló bizottság felállítása, az eredmény kihirdetése. E metódus a korszak végére széles körben bevett gyakorlattá vált, középületek esetén a nyílt tervpályázat általánossá vált, míg a magánpályázatokon inkább a meghívásos rendszer dominált. Az építtetők egy külön csoportjának tekinthetőek az egyházak, melyek a kutatás által feltárt esetekben a nyílt pályáztatást alkalmazták.

A pályázati kiírások tartalma és formája kulcsfontosságú a folyamat során, nem véletlen, hogy a szakma igyekezett a sajtóban ezzel újra és újra foglalkozni. Részletes tervezési program nem mindig állt rendelkezésre, összességében a kírások pontossága igen változó színvonalú volt. A hirdetések során végigtekintve megállapítható, hogy a tervezők számára legelemibb információk a határidő, a díjazás, és az építési költségplafon voltak. Ezek szerepeltetése jellemző a kiírásokban. Megfigyelhetö, hogy e paraméterek ideális megállapítása esetén a pályázat sikeres tudott lenni, ilyenkor nagyságrenddel több terv érkezett be, mint egy rosszul megfogalmazott kiírás esetén. ${ }^{106}$ Megfigyelve a méltatlankodó publicisztikákat, leginkább a rossz tervezési programot, a túl rövid határidőt és az elégtelen díjazást kifogásolták.

\subsection{INDULÓK - RÉSZTVEVÖK}

Nemzetközi tervpályázatok esetén lehetett a legszélesebb a résztvevők köre, ilyenkor az indulók személyére nem alkalmaztak megkötést. ${ }^{107}$ Hazai pályázatoknál leggyakrabban a magyar állampolgárság volt a feltétel, az építész végzettség nem, az Egylet pályázatain pedig természetesen csak a tagok indulhattak. Építészek és építőmesterek egyaránt rendre pályáztak, illetve éppen a korszakban különváló építészi és mérnöki feladatkörök következményeképp a jelentős szerkezeti problematikájú pá-

${ }^{106}$ Például az 1892-es eszéki iskolapályázatra, a hasonló léptékü és jellegü pályázatokon ekkor megfigyelhető átlagosan 5-15 pályázóval szemben, 79 pályamü érkezett be; köszönhetően a jól sikerült pályázatkiírásnak. VL (1892) 47. 2. A bírálatról beszámoló cikk méltatja a lebonyolítás példás mivoltát, és megemlíti, hogy még külföldi pályázók is indultak. VL (1892) 51. 3.

${ }^{107} \mathrm{Az}$ első világháború alatt előfordult, csak háborús szövetségesek számára meghirdetett pályázat, ezen tehát csak magyar, osztrák és német építészek indulhattak. 
lyázatokon az építészek mérnökökkel társultak, ahogyan emlékmüpályázatoknál képzőmüvészekkel, leginkább szobrászokkal együtt vettek részt a versenyben. A korszak folyamán induló pályakezdők közül életművük előrehaladtával több építész munkásságában is megfigyelhető a pályázatokon elnyert tervezési megbízások arányának fokozatos növekedése. ${ }^{108}$

\subsection{PÁLYÁZATI FORMÁK}

Az építészeti pályázat két alapvető eljárási variációja a nyílt és a meghívásos forma, melyek közül mindkettő alkalmazására látunk példákat a korszakban. Az általános középítési feladatok esetében szükségesnek tartották a nyílt pályázatot - legalábbis első körben. Meghívásos tervverseny kiírására jellemzően két esetben folyamodtak. Egyfelől, ha egy megelőző nyílt pályázat eredménye nem volt egyértelmü, ilyenkor második kört írtak ki, melyre az első forduló sikerültebb terveinek szerzőit hívták meg. Ez a többlépcsős pályáztatás már a XIX. században jellemző volt, de sosem elöre eltervezett módon, mindig az első forduló eredményének ismeretében, ad hoc határoztak a második körről, tehát elmondható, hogy a gyakorlatban ismerték és alkalmazták a többlépcsős formát, belátva annak előnyeit, mégsem vált gyakorlattá az előre tervezetten több fordulós pályázatok kiírása. Másrészt jellemzően a magánépíttetők voltak, akik inkább már egy előzetes szürőként élve a lehetőséggel hívtak meg építészeket - így épültek a bankok és a biztosítótársaságok székházai, a magántulajdonú középületek.

Egyértelmü, hogy a pályázatok titkosak voltak, ${ }^{109}$ a jeligés boríték mellékelése a kiírások jó részében szerepel - összhangban a pályázat lényegével. ${ }^{110}$ Ezáltal a névaláírásos pályáztatás csak különleges esetben jött szóba, illetve mikor a kiírók nem voltak teljesen tisztában a tervverseny elvi követelményeivel; számos esetben a névaláirás megkövetelése által kiváltott tiltakozás késztette gyors korrekcióra az építtetőket. ${ }^{111}$ A jeligés borítékokat csak a díjazott vagy megvásárolt tervek esetében nyitották fel, így nem sértve a - kiírásban is ígért - titkosság elvét. ${ }^{112}$

${ }^{108}$ Pl. a Girgl-Korb építészpáros, Medgyaszay István, Alpár Ignác és a Komor-Jakab páros életműveiben.

${ }^{109} \mathrm{Az}$ egyéb történelmi folyamatokkal párhuzamosan a titkos-jeligés pályázati gyakorlat 1956 után szünt meg. Urbán Erzsébet - Vukoszávlyev Zorán: Árkay Bertalan templomépítészete a második világháború után. Architectura Hungariae 15 (2016) 1. 1-36.

${ }^{110}$ Például a lipótvárosi zsinagóga pályázati hirdetményében 1898-ban, $V L$ (1898) 8.8 vagy a füzesgyarmati református iskola 1910-es pályázatának kiírásában, ÉPIP (1910) 242.

${ }^{111}$ Többek közt például a debreceni városháza átalakításának pályázata 1894-ben, ÉPIP (1894) 288, illetve a hódmezővásárhelyi szálloda versenye 1899-ben, VL (1899) 38. 2.

${ }^{112}$ Ismerünk híradást arról, hogy a bírálóbizottság jelenlétében semmisítették meg a feloldatlan jeligék borítékjait: balmazújvárosi városháza pályázata 1902-ben. VL (1902) 28. 3. 


\subsection{A LEBONYOLÍTÁS}

A megbízó által életre hívott építési bizottság feladatai közé tartozott - legtöbb esetben - a pályázat kiírása, bár általában a hirdetményt valamilyen hatóság vagy hivatalos személy jegyezte aláírásával. Kisebb projekteknél a koordináló-ellenőrző szerepet maga a városi tanács vagy az építtető intézmény igazgatósága végezte. A pályamüvek beérkezése után azonban ritkán végezte maga a kiíró a bírálatot, bíráló bizottságot hoztak létre. Ebbe két körböl válogatták be a tagokat, az egyik az építészeti minőség érdekében független építész szakemberek csoportja volt, míg a másik az építtető érdekeit képviselendő hivatalos személyek. Alapvetően ennek a két csoportnak az egyensúlyán múlt egy-egy pályázat bírálatának sikeressége, ha egyik vagy másik szempont felülkerekedett, akkor jellemzően az eredmény nem elégítette ki a szereplöket. ${ }^{113}$

Rendszeresen előfordultak visszásságok, melyek több esetben is botránnyá fajultak, amikor a szakmai viták a szélesebb közvélemény elé kerültek; ezek emlékezete gyakran túlnőtt önmagán, városi legendákat szülve. ${ }^{114} \mathrm{E}$ botrányok legföbb okai a szabályzatok hiányosságai vagy épp be nem tartása voltak; a konfliktusok a versenyző tervezők és a leendő megbízó építtetők közti érdekellentétből fakadtak. Nagy vihart kavart például a New York palota 1891-es meghívásos pályázata, ahol a nem nyertes pályázók - és támogatóik - kritizálták a bíráló bizottságot, amelynek egyetemi praxissal rendelkező tagjai és a szintén egyetemi kötődésủ pályázók között összejátszást feltételeztek a „magánépítész” indulók rovására. ${ }^{115}$ Az Erzsébet királyné emlékművére kírt pályázatokon az váltott ki botrányokat, hogy a nagy társadalmi elvárás, a bőkezű adományokból összeállt túl magas költségkeret a tervezési folyamat béklyójává vált, a szoborterv városrendezéssé nőtte ki magát, amibe végül belebukott a beruházás. Végül csak az első világháború után készült el az emlékmü. ${ }^{116}$

Folyamatosan feszültséget okozott a dualizmus korszaka alatt a színháztervezések ügye. A hazai építészszakma ellenszenvét váltotta ki a bécsi Helmer és Fellner építészpáros, akik kifejezetten színházépületekre specializálódva, minden esetben rövid határidővel és a hazai versenytársaknál olcsóbban vállalták a tervezést, ezzel gyakorlatilag teljesen kiszorítva a magyar építészeket a teátrumok tervezésének piacáról.

\footnotetext{
${ }^{113}$ Például a rozsnyói zsinagóga esete, ahol a sajtó a gyülekezet túlzott befolyását tette szóvá a pályázat elbírálásában. $V L$ (1892) 15. 2.

${ }^{114}$ Például az Országház 1882-es pályázatán a négy egyenrangú első díj kiosztását érthette félre a közvélemény, ugyanis máig tartja magát a hiedelem, miszerint a Parlamenttel szemközt álló két épület, a Kúria (Hauszmann Alajos, 1896) és a Földművelésügyi Minisztérium (Bukovics Gyula, 1885) az Országház pályázatának 2. és 3. helyezett tervei szerint épültek.

${ }^{115}$ Vadas Ferenc: Épitészettörténeti tudományos dokumentáció a Szentháromság téri volt pénzügyminisztérium épületéröl. 1998.

${ }^{116}$ Székely Márton - Marótzy Katalin: Erzsébet királyné budapesti emlékmüvének pályázatai 1890-1920. Architectura Hungariae 14 (2015) 2. 37-50.
} 
Az osztrák tervezőpáros heves bírálatokat váltott ki a magyar építészeti közéletben, hiszen a színházpályázatokat többnyire ők nyerték - a magyar szakma szerint nem mindig megérdemelten. ${ }^{117} \mathrm{~A}$ korabeli szaksajtóból kitünik, hogy a pályázatok lebonyolításának tisztasága milyen neuralgikus pont volt a szakma számára. Ahogy később, már ekkor is a nyugati orientáció jellemezte a mintakeresést: a nyugat-európai országok pályázati kultúrájának vélt fejlettségére rendszeresen utaltak. ${ }^{118} \mathrm{~A}$ témára reflektált egy cikksorozat 1908-ban, melyben külföldi botrányokat tártak a magyar olvasók elé, avval a felhanggal, hogy még az amúgy idealizált nyugaton sem minden tökéletes, és a tervpályázatokon ott sem ismeretlenek a visszásságok. ${ }^{119}$

\subsection{A PÁLYATERVEK NYILVÁNOSSÁGA}

A pályázatok tervanyagainak sorsa legtöbb esetben igencsak hányatott. Mivel a pályázat lezárulta után a nem díjazott terveket igyekeztek visszaszolgáltatni a pályázóknak, vagy legalábbis visszavételre felszólították őket, a pályamunkák sorsa tervezőjük gondosságán múlt, ami igen változó volt, és az anonimitás miatt néhol a tervező azonosítása is kérdéses. A század végéig egy-egy pályázat teljes tervanyagát egyben csak a kiállításokon láthatta a nagyközönség, ${ }^{120}$ de ekkor még nem dokumentálták a pályamunkákat, így legtöbb esetben a századfordulóig csak leírásokból alkothatunk némi képet ezek építészeti minőségéről. A sajtó csak a XX. század elején kezdte következetesen a pályázatok tervanyagának teljességre törekvő publikálását, az ez elötti pályatervek legfeljebb a tervező hagyatékában lelhetők fel, ott is csak szerencsés esetben. Ahogy az 1900-as évek elejétől a nyomdaipari fejlödésnek köszönhetően széles körben és nagy mennyiségben kezdtek közreadni terveket, láthatólag csökkent a kiállítások fontossága, melyek az 1890-es években még jóval jelentősebb eseményeknek számítottak. ${ }^{21}$

\footnotetext{
${ }^{117}$ Jellemző példa az ellentétek megnyilvánulására a kecskeméti színház pályázatának 1895-ös botránya, mikor az elsődíjas Helmer-Fellner-tervről a magyar szakemberek úgy gondolták, meg sem felel a pályázati programnak. VL (1895) 34. 1.

${ }^{118}$ Részletes, elismerő hangvételű beszámoló a Kaliforniai Egyetem tervpályázatáról. ÉPIP (1900) 155, 159. Jellemző idézet a Megbízás vagy pályázat? című cikkből: „Németországban, a tervező pályázatok classicus hazájában, ahol még a kényesebb lakásbelsőket is pályáztatják (...)” ÉPIP (1907) 258.

${ }^{119}$ Rövid, szemléletes negatív példákkal illusztrált, olvasói levelek alapján írt szerkesztőségi cikkek jelentek meg német pályázatokról: MMÉEHÉ (1908) 304, illetve francia pályázatokról: MMÉEHÉ (1908) 324.

${ }^{120}$ Például az Operaház pályaterveinek kiállítása az MTA-n. Czétényi Piroska - Szvoboda Gabriella: $A z$ Operaház. Képzőművészeti Kiadó, Budapest 1987.

${ }^{121}$ Például a New York palota 1892-es pályaterv kiállítása az Egylet székházában.
} 


\subsection{A PÁLYÁZATOK SZÁMA ÉS ELOSZLÁSA}

A tárgyalt 30 éves periódus alatt több mint 800 pályázat kiírásáról van adatunk, ${ }^{122}$ melyeknek kevesebb mint egytizede külföldi. Határozott tendencia figyelhető meg az időbeliségben: átlagosan évente 30 pályázatot írtak ki, a korszak elejétől az első világháború előestéjéig folyamatos lassú növekedést láthatunk, mely drámaian megtorpant és visszafordult a világégés kezdetével. Határozott anomália észlelhető 1899-1903 között, amikor a kírások száma hirtelen megtizedelődik, majd ugyanilyen hirtelen visszaáll a Millennium körüli számra. ${ }^{123}$ 1910-ben éri el a csúcsot: ebben az évben 60 építészeti pályázatot hirdettek meg a hazai szaksajtóban. Megfigyelve a pályázatok települési eloszlását, egyértelmüen szembetünik Budapest túlsúlya, az összes kiírás több mint negyede szólt a fövárosi helyszínekre. Ez is alátámasztja, hogy bár ekkor még csak az ország lakosságának 5\%-a élt Budapesten, a polgári és gazdasági fejlődés itt összpontosult. A vidéki városok pályázatkiírásainak számát érdemesebb lakosságuk arányában szemlélni, ebből következtethetünk a pályáztatás elterjedtségén keresztül az egyes települések polgárosultságára is. Népességarányosan vizsgálva a fejlettebb nagyvárosok némelyike Budapesttel azonos arányszámot mutat (Arad, Szombathely, Nagyszeben, Szolnok); egyes, kisebb városok jóval felül is múlják (Veszprém, Beszterce). A nagyvárosok közül néhány azonban egyértelmüen elmarad a lakossága alapján elvárható számoktól (Debrecen, Pozsony, Hódmezővásárhely). Ennek kapcsán meg kell jegyezni, hogy a vidéki lapok tanulmányozása még tovább árnyalhatja a képet, a kutatás során eddig csak az országos szaksajtó részletes tanulmányozása történt meg.

A funkciók szerinti eloszlást vizsgálva látható, hogy kevés pályázatot hirdettek lakóépületekre, katonai objektumokra, ipari létesítményekre. ${ }^{124}$ A lakóépületeket jellemzően nagyvárosi bérházakat - megrendelőik leginkább közvetlen megbízással terveztették, ezekre pályázatot ritkán találunk. ${ }^{125} \mathrm{Az}$ érzékenyebb állami tervezési feladatokat gyakran látták el a megbízhatónak tartott minisztériumi építészek, ${ }^{126} \mathrm{a}$ gyártulajdonosokat pedig természetesen nem kötelezhette senki pályáztatásra. Egyértelműen az állami (közigazgatási, oktatási stb.) pályáztatások túlsúlya jellemzi

${ }^{122} \mathrm{Az}$ ÉPIP, az MMÉEK, az MMÉEHÉ, a VL és a Vállalkozók Közlönye számai, valamint az utóbbi évtizedek építészettörténeti szakirodalma alapján készült összesítés alapján, mely tartalmaz minden pályázatot, amelyet a vizsgált források említenek. Az esetek túlnyomó többségében a kiírás helyéről, időpontjáról és tárgyáról van adatunk, míg az eredményről, a pályatervekről jóval kevesebb információ áll rendelkezésre - azok is jellemzően inkább a nagyobb volumenü tervversenyeknél.

${ }^{123} \mathrm{~A}$ pályázatok számának ilyen mértékủ hirtelen csökkenése bizonyosan az építőipar általános válságának volt a következménye, melyre a sajtó ekkoriban többször is utalt. E válságot feltételezhetően Széll Kálmán kormányának drasztikus kiadáscsökkentése okozta, amellyel a megelőző fél évtizedben a millenniumi építkezések generálta költekezést kívánták ellensúlyozni.

${ }^{124}$ Egy ellenpélda a kolozsvári laktanya bövítése 1891-ben. VL (1891) 20. 2.

${ }^{125}$ Üdítő kivétel Trummer János bérházának pályázata. ÉPIP (1905) 69.

${ }^{126}$ A pénzügyminisztérium tervezésére való megbízást például Fellner Sándor a miniszterrel egy vadászaton történt szóbeli megegyezés alapján kapta meg. Vadas Ferenc: Építészettörténeti tudományos dokumentáció a Szentháromság téri volt pénzügyminisztérium épületéröl. 1998. 
a kort. Az 1886-os közigazgatási reform következményeképp számos város- és megyeháza pályázatot írt ki, ${ }^{127}$ és jelentős arányban találunk kiírásokat emlékmüvekre is. ${ }^{128}$ Szintén nagyobb számban találhatunk belsőépítészeti, városépítészeti témájú, ${ }^{129}$ illetve szakmai szervezetek által kiírt fiktív pályázatokat. ${ }^{130}$

\section{JELENTÖS PÁLYÁZATI ESEMÉNYEK 1891-1920 KÖZÖTT131}

A kutatás tárgyát képező évtizedek szakmatörténeti szempontból legjelentősebb tervpályázatainak sorában elsőnek az Erzsébetvárosi plébániatemplom tervversenyét kell említenünk, melyet bár korábban írtak ki, eredményhirdetése szinte egybeesett Ybl mester halálhírével. E hazai, nyílt pályázat eredményét az 1890-es évtized elején még kivételesnek számító teljességgel publikálták. ${ }^{132}$ Átfogó képet kaphatunk mindhárom díjazott tervről, melyeken híven tükröződnek a már stíluskeverő korszakába lépő historizmus alkotói módszerének sajátosságai. ${ }^{133} \mathrm{Az}$ évtized legelején két másik reprezentatív tervverseny foglalkoztatta a szakmai közvéleményt: a kecskeméti városháza és a budapesti Iparmüvészeti Múzeum pályázatai, melyeken a díjazott pályamunkákat részletesen, illusztrálva mutatták be. ${ }^{134} \mathrm{E}$ két pályázat terveinek stílusbeli sokfélesége hü képet ad a korabeli hazai építészeti ízlés változásáról, ${ }^{135}$ mely végül meghozta Lechner újszerü formavilágának váratlan sikerét is. A nagyszabású kormányzati középületekre kiírt versenyek mellett egy igen jelentős és a hazai építészeti közélet fokozott érdeklődését kiváltó pályázat is lezajlott 1891-ben, melyet egy külföldi magáncég, az amerikai New York Életbiztosító Társaság írt ki. A nemzetközi

${ }^{127}$ Például a rimaszombati vármegyeháza, ÉPIP (1897) 38 vagy a soproni városháza, ÉPIP (1892) 303.

${ }^{128}$ Például az Andrássy-szobor, ÉPIP (1892) 338, illetve az Ybl-szobor Budapesten, ÉPIP (1894) 101. A legnagyobb visszhangot kiváltó emlékműpályázat-folyam Erzsébet királyné budapesti emlékmüvének többfordulós tervversenye volt 1890-1920 között. Ennek részleteiről bővebben: Székely Márton - Marótzy Katalin: Erzsébet királyné budapesti emlékmüvének pályázatai 1890-1920. Architectura Hungariae 14 (2015) 2. 3750 .

${ }^{129}$ Budapesten a volt Újépület - a későbbi Szabadság tér - területének rendezésére írta ki az Egylet 1892-es kispályázatát, VL (1892) 10. 3; belsőépítészeti pályázatok közül említhető például az Egylet 1894-es faburkolatú mennyezet pályázata, ÉPIP (1894) 97.

${ }^{130}$ Például az Egylet 1894. évi nagypályázata: Vidéki város fürdőépülete, ÉPIP (1894) 148 vagy az 1906-os egyleti pályázat a Batthyány-örökmécsesre, ÉPIP (1906) 109.

${ }^{131}$ Vizsgált korszakunkat 1920 zárja, jelentős pályázati esemény azonban a tízes évek végéröl - a történelmi körülmények miatt - nem említhető.

${ }^{132}$ ÉPIP (1891) 49, 53, 60, 85, 97.

${ }^{133} \mathrm{Az}$ 1890-es pályázat három díjazott tervének szerzői: Steindl Imre (I. díj), Pecz Samu (II. díj) és Aigner Sándor (III. díj); pályamunkáik a templomépítészet történetének különböző jellemző stílusait és térszervezés-típusait vonultatják föl. A megbízást végül Steindl Imre nyerte hosszházas, kéttornyos csarnoktemplomot vizionáló tervével, mely kisebb módosításokkal 1895-1901 között épült meg. Sisa József: Steindl Imre, i. m. 166.

${ }^{134}$ Kecskeméti városháza: Kolbenheyer Viktor terve: MMÉEK (1892) 104; Lechner-Pártos páros terve (I. díj): MMÉEK (1892) 165; Lang-Steinhardt páros terve: MMÉEK (1892) 130. Végül Lechner terve alapján készült el az épület.

${ }^{135} \mathrm{Az}$ első díjat és a megbízást is Lechner kapta, a múzeum 1896-ban nyílt meg. Ács Piroska: $A z$ Iparmüvészeti Múzeum palotájának épitéstörténete. Iparmüvészeti Múzeum, Budapest 1996. 
terjeszkedést előirányzó vállalat elhatározta, hogy több európai fóvárosban kíván luxusbérházakat építeni reklámcéllal és helyi leányvállalatuk székhelyéül. Budapest is a célvárosok közé került, ezért meghívásos pályázatot írtak ki a fővárosba tervezendő épületre. ${ }^{136}$ A verseny azonban nem volt nemzetközi, a társaság úgy döntött, hogy meghatározó magyarországi építészeket hív meg. ${ }^{137}$ Nyolc beérkezett pályamü elbírálása után végül a hazai építészekből álló szakmai zsüri döntését a New York-i igazgatóság jóváhagyta, a megbízást Hauszmann Alajosnak ítélve. ${ }^{138}$ E pályázat jelentőségét mutatja az is, hogy két évvel később valamennyi pályatervét publikálták, ${ }^{139}$ emiatt ez az általunk legrészletesebben ismert meghívásos pályázat a tárgyalt korszak első feléből. A nemzetközi hátterű projekt hazai versenyzők számára kiírt pályázata után két fóvárosi beruházásra meghirdetett, nemzetközi nyílt pályázat keltett nagy visszhangot: a Központi Vásárcsarnok 1892-ben, és a két új Duna-híd 1894-ben kiírt tervversenye. A vásárcsarnok 1892 decemberi határidejére öt országból kilenc pályaterv érkezett be, végül a kétkörös szavazáson Pecz Samu terve győzött. ${ }^{140}$ A budapesti Duna-hidak pályázatára 76 pályamü érkezett be, melyek között igen látványos terveket is találhatunk. ${ }^{141} \mathrm{~A}$ két hídra beadott pályázatokat együtt bírálták el, ${ }^{142}$ az első díjat egy Eskü téri, míg a második és harmadik díjakat egy-egy Fővám téri hídra vonatkozó terv nyerte el. ${ }^{143}$ Az 1890 -es évtized közepén az ország közvéleményét lázban tartó Ezredéves Kiállítás területrendezésére és létesítményeire is országos nyilvános pályázatokat hirdettek. Ezek közül a legnagyobb visszhangot a történelmi épületcsoport 1893/94-es versenye keltette, mely a többlépcsős tervpályázat egyik első eredményes példája volt Magyarországon. ${ }^{144}$ Az emblematikus épületegyüttes tervezésének megbízását - a Millenniumhoz méltónak tartott nemzeti egység jegyében - két pályázó: Alpár Ignác és Schickedanz Albert együtt kapta meg. ${ }^{145}$ A kiállítás területén lévő városligeti tó fölé építendő hídra kiírt 1893-as pá-

\footnotetext{
${ }^{136}$ A programba az említett funkciókon kívül még belekerült egy kávéház az épület földszintjén, melynek az építtető attrakció jelleget szánt; a pályázóktól külön belsőépítészeti részletterveket kértek ezen térsorra. Vadas Ferenc: Tudományos dokumentáció. New York palota és kávéház. 1995. (Forster Központ, Tervtár ltsz. 46110.) 32.

${ }^{137}$ Bukovics Gyula, Hauszmann Alajos, Bobula János, Freund Vilmos, Pecz Samu, Quittner Zsigmond, Ulrich Keresztély, Lang Adolf-Steinhardt László páros. Vadas Ferenc: i. m. 32.

${ }^{138}$ A pályázat eredménye nagy felzúdulást váltott ki, egyesek biztosra vették a verseny manipulálását, szakmailag nem megfelelőnek ítélve a győztes tervet, ellenben méltatva a nem díjazottakat. Hauszmann torony nélküli pályatervét módosítva Ulrich pályamúvén lévőhöz hasonló tornyot tervezett, az építtető kérésére. A palotát és a kávéházat végül 1894 októberében vehette használatban a nagyközönség. Vadas Ferenc: i. m. 42.

${ }^{139}$ MMÉEK (1892) 321; MMÉEK (1893) 29, 97,193, 265, 393, 396.

${ }^{140}$ A kilenc pályázat közül négy érkezett Budapestről, illetve egy-egy Berlin, Lipcse, Szófia, Prága és Párizs városából. A bíráló bizottság titkos szavazással három első és két második díjat osztott ki.

${ }^{141}$ Több díjazott és megvásárolt pályatervet közölt a szaksajtó. MMÉEK (1894) 329, 347, 452.

${ }^{142} V L(1894) 30.3$.

${ }^{143}$ I. dijj: Eisenlohr és Weigle, stuttgarti építészek terve; II. díj: Feketeházi János terve; III. díj: Gregersen és fiai - Schmahl Henrik terve. VL (1894) 24. 2.

${ }^{144}$ Gerle János: Századfordulós stílusirányzatok. In: Magyarország építészetének története. Szerk.: Sisa József - Dora Wiebenson. Vince Kiadó, Budapest 1998. 250.

${ }^{145}$ A városligeti Vajdahunyadvár pályázatának történetéről bővebben: Rosch Gábor: Alpár Ignác épitészete. Enciklopédia Kiadó, Budapest 2005. 42-58.
} 
lyázat sajátossága volt, hogy nagy hangsúlyt fektetett a tartószerkezeti szempontokra. Ez volt az egyik első alkalom, hogy a pályázók között nevesített társtervezőként jelentek meg a szerkezettervezők, a pályamunkák pedig részletesen kitértek a javasolt szerkezeti megoldásokra. ${ }^{146}$ A századforduló éveinek virágzó templomépítkezésein egyre nagyobb arányban alkalmaztak nyilvános pályázatot a tervek beszerzésére - követve az állami szektorban már elterjedt gyakorlatot. Budapesten a Lipótvárosba tervezett grandiózus zsinagógára hirdettek pályázatot 1899-ben, melynek pályamüveiből nagy érdeklődést kiváltó kiállítás született, de a megvalósulás elmaradt. ${ }^{147}$ Hasonlóan nagy szakmai figyelem kísérte a szegedi Fogadalmi templom 1904-es pályázatát, melyen a 35 beérkezett terv közül egyiket sem ítélték elsődíjasnak, a városvezetés később Schulek Frigyest ${ }^{148}$ bízta meg a tervezéssel. ${ }^{149} \mathrm{Az}$ emlékmüvek pályázatai tárgyuk természeténél fogva mindig kiemelt figyelmet kaptak; a század első éveiben leginkább két reprezentatív fővárosi emlékmü foglalkoztatta a közvéleményt: Kossuth Lajos és Erzsébet királyné emlékmüvei. Párhuzamosan zajlott Kossuth Országház téren felállítandó szobrának és Kerepesi temetőbeli mauzóleumának pályázata is. Előbbi csak az 1920-as években valósult meg, a síremlék azonban Gerster Kálmán ${ }^{150}$ terve nyomán 1909-re felépült. ${ }^{151}$ Az Erzsébet királyné nagyszabású emlékmüvére több fordulóban meghirdetett tervpályázatok sora jó példája az építészek és szobrászok közös munkájának, a két mesterség pályázói minden esetben párba álltak az induláskor. A tragikus emlékü királyné emlékmüve a korszak egyik legjobban illusztrált pályázatfolyama, ezen tervek jelentősége messze túlmutat magán az építményen. ${ }^{152}$ A korszakban egyre fejlődő pénzügyi szervezetek folyamatosan fejlesztették épületállományukat - a magánbankok és az állami szektor is. Két igen reprezentatív épület tervpályázata zajlott le a századforduló évében, szinte párhuzamosan - a két talán legfontosabb pénzügyi középületünké: az Osztrák-Magyar (később Nemzeti) Banké és a Tőzsdepalotáé. Mindkét pályázatot a pénzügyi intézmények szinte szakértőjévé váló Alpár Ignác nyerte, s az épületek valóban az ő tervei alapján készültek el. ${ }^{153}$ Nemcsak egyes épületek, de jelentősebb városrendezési kér-

${ }^{146} \mathrm{Az}$ első díjat Giergl Kálmán és Korb Flóris építészek, valamint Zielinszky Szilárd mérnök terve kapta. MMÉEK (1895) 203.

${ }^{147}$ A beérkezett 23 terv közül az első díjat Förk (Foerk) és Schömer, a másodikat Bálint és Jámbor kapták, a harmadikat Leöffler Béla. ÉPIP (1899) 85.

${ }^{148}$ Schulek Frigyes (1841-1919) magyar építész.

${ }^{149}$ A II. díjat Aigner Sándor és Rainer Károly, a III. díjat Förk (Foerk) Ernő és Sándy Gyula kapták. Miután Schulek viszalépett, 1912-ben Förk Ernőt bízta meg a város a tervek átdolgozásával és az építkezés müvezetésével. ÉPIP (1912) 134.

${ }^{150}$ Gerster Kálmán (1850-1927) magyar építész.

${ }^{151}$ Az 1900-ban kiírt pályázaton először a Bálint-Jámbor páros terve lett az első, de a szecessziós tervről kirobbant élénk vita folyamán végül - többek közt Kossuth fiának közbeavatkozása miatt - Gerster Kálmán és Stróbl Alajos kapták a megbízást. Az építkezés 1903-1906-ig tartott. ÉPIP (1910) 54.

${ }^{152}$ A közölt nagyszabású pályaterveken végigkövethetjük a századelő építészeti stílusainak egymás mellett élését. Részletesebben: Székely Márton - Marótzy Katalin: Erzsébet királyné budapesti emlékmúvének pályázatai 1890-1920. Architectura Hungariae 14 (2015) 2. 37-50.

${ }^{153}$ Részletesebben lásd: Németh Nóra - Marótzy Katalin: Stíluskérdések a századfordulón - Két építészeti pályázat háttere. Épités - Épitészettudomány 41 (2013) 3-4. 253-270. 
dések megoldására is egyre gyakrabban rendeztek nyilvános pályázatot, többek közt a Gellérthegy architektonikus rendezésére ${ }^{154}$ és a budapesti Szabadság tér kialakítására, ${ }^{155}$ melyek nyomán később sikerült az urbanisztikai feladatokat megoldani. A huszadik század első évtizedének derekán több országos jelentőségü, nyilvános középület pályázatára került sor. Ezek közül a Kolozsvári Egyetemi Könyvtár 1904es pályázata ${ }^{156}$ nyomán el is készült az épület, azonban több jelentős fóvárosi pályázat eredményessége ellenére, nem valósult meg - e versenyeket a közölt pályatervek alapján vizsgálhatjuk. ${ }^{157}$ A Rudas és Sáros fürdők pályázatai párhuzamosan zajlottak, és mint a Gellért-hegy lábainál található, városképi jelentőségü leendő épületek, sok tervezőt csábítottak részvételre. Az eredmény alapján második, meghívásos fordulót rendeztek 4-4 pályázó számára. ${ }^{158}$ Mikor a szakma által szinte egyhangúlag sikertelen épületnek tartott Földmüvelésügyi Minisztérium épületének felújítása napirendre került, átépítése mellett döntöttek; külön homlokzati és alaprajzi pályázatot hirdetve. A nívós pályaterveket kiállították, de az építkezés pénzhiány miatt végül elmaradt, ${ }^{159}$ az épület ma is eredeti megjelenését őrzi. A kispesti munkáslakótelep elrendezésére és háztípusaira kiírt pályázat igen előremutató volt tárgyát tekintve, és ideális lefolyását is kiemelte a sajtó. ${ }^{160} \mathrm{~A}$ később Wekerletelep néven felépült városrész Budapest első modern kertvárosra tett - sikeres - kísérlete is volt egyben. Az 1900-as évtizedben a nyilvános középületek esetén már egyre inkább rutinná váló pályáztatás kezdett magánépíttetői körökben is jobban elterjedni, ${ }^{161}$ melynek jó példái a budapesti belváros banképítkezései. A Pesti Kereskedelmi Bank 1905-ben, a Belvárosi Takarékpénztár 1908-ban hirdetett tervversenyt új székház építésére. ${ }^{162}$ A háború előtti utolsó tervpályázatok közül négy nagyszabású fóvárosi középület versenyét kell kiemelnünk. Közös jellemzőjük a magas színvonal - készítőik ekkor már rutinos pályázók - és a tervek stílusbeli sokszínűsége, ami a késő historizmus legutolsó szakaszától a különféle századfordulós tendenciákon át egészen a premodernig ível, gyakran egyazon tervben ötvözve mindhárom irányzat vonásait. A Nemzeti Színház 1913-as pályázatán a kor legjelesebb építészei vonultak fel, a modern elrendezésű

${ }^{154}$ ÉPIP (1900) 12.

${ }^{155}$ ÉPIP (1892) 63.

${ }^{156}$ ÉPIP (1904) 228.

${ }^{157}$ Például a Kultuszminisztérium monumentális palotájának 1905-ös pályázata, melyen az I. díjat Alpár Ignác kapta. Magyar Pályázatok (1905) 9. 1, illetve a fővárosi közkönyvtár 1911-es pályázata, ahol a Menyhért Miklós - Rerrich Béla páros lett az elsődíjas. Magyar Építőmüvészet (1911) 8. 1.

${ }^{158}$ A Sáros fürdő pályázatára 36, míg a Rudaséra 39 terv érkezett be. ÉPIP (1905) 294. A Rudas fürdő átépítése elmaradt, a Sáros fürdő végül Gellért fürdő néven épült meg Sebestyén Artúr és Hegedűs Ármin tervei alapján. ÉPIP (1918) 125.

${ }^{159} 20$ terv érkezett be, mindkét pályázatot Tőry Emil nyerte. ÉPIP (1907) 135.

${ }^{160}$ Palóczi Antal organikus úthálózatot vizionáló terve nyerte a I. díjat. ÉPIP (1908) 419.

${ }^{161}$ ÉPIP (1907) 226.

${ }^{162}$ A Pesti Kereskedelmi Bank versenyét Alpár Ignác nyerte, és ő is kapta a megbízást, míg a Belvárosi Takarékpénztár pályázatán három első díjat osztottak ki, de végül a megbízást Schmahl Henrik kapta - aki nem is volt az indulók között. Kelecsényi Kristóf - Torma Ágnes: Schmahl Henrik (1846-1912), egy német kőműveslegény felemelkedése a dualizmus kori Budapesten. In: Épitömüvészek Ybl és Lechner korában. Szerk.: Rozsnyai József. Terc Kiadó, Budapest 2015. 122-130. 
színház legjobb megoldását keresve - az egyébként sok szakember által alkalmatlannak tartott Múzeum körúti telekre. ${ }^{163}$ A mai Széll Kálmán térre tervezett budai zsinagóga ${ }^{164}$ és a hatalmas, Rezső téri Ferenc József- emléktemplom ${ }^{165}$ 1914-es pályázatai lettek a békeidők utolsó szakrális témájú tervversenyei. Míg a zsinagógánál progresszív felfogású terveket találunk, a Rezső téri templom terveire inkább a merev historizálás jellemző, a program ott ugyanis - akkoriban már igen szokatlan módon - határozottan elöírta a román stílust. ${ }^{166}$ Az Osztrák-Magyar Monarchia összeomlása előtti utolsó jelentősebb, publikált eredményü pályázat a budapesti köztemetőbe tervezett krematórium volt 1916-ban. ${ }^{167}$

\section{6. ÖSSZEGZÉS}

Ha végigtekintünk a kiemelten publikált, illusztrált és a közvélemény érdeklődését leginkább kiváltó pályázatok során, akkor három nagy szakasz rajzolódik ki. Az első a Millenniumi Kiállítás eseményei köré csoportosuló pályázatok sora volt. Egyrészt a Kiállítás eseményeihez kapcsolódóan készültek ideiglenes és állandó épületek, másrészt a „modern” állam reprezentációját erősítő középületek megvalósítására is manifesztálódott az igény. A második időszakot, az 1896-os túlköltekezés utáni visszaesést követően - a századfordulótól az 1910-es évek elejéig tartó periódust - három épülettípus pályázatai dominálják. Elsősorban reprezentatív emlékmüvek, illetve nagyszabású szimbolikus középületek, másodsorban pénzintézetek, bankok - tehát magánépíttetők - pályázatai fordultak elő legtöbbször. E századfordulós időszak sikeres tervpályázatainak eredményeképpen több - máig fennálló - országos jelentőségű középület valósult meg. ${ }^{168}$ A harmadik szakasz, az I. világháború előtti utolsó évek nagyszabású tervversenyei sikeresek voltak, az addiginál is nagyobb közfigyelmet és sajtónyilvánosságot kaptak, ${ }^{169}$ a háborús körülmények miatt végül az épületek nem valósulhattak meg. E pályázatok építészettörténeti jelentősége abban áll, hogy pusztán terv formában is jól jellemzik koruk építészetének fejlettségét.

Általánosságban elmondható, hogy a hazai építészeti közélet által mindvégig kiemelten kezelt pályázati intézmény a tárgyalt korszak alatt jelenősen fejlődött, a kiírt pályázatok száma - a gazdasági körülményeknek nagyban kiszolgáltatva - nött.

${ }^{163} \mathrm{Az}$ I. díjat Medgyaszay István terve nyerte. MÉM (1913) 1. 2.

${ }^{164}$ Löffler Béla nyerte az I. díjat, de kivitelre nem alkalmasnak, csak „,az alapeszmét magában foglalónak” minősítették. ÉPIP (1914) 57.

${ }^{165}$ I. díj: Lechner Ödön, II. díj: Kauser József, III. díj: Takách és Tornallyay, IV. díj: Foerk Ernő. Megvétel: Hoffhauser Antal és Wiesner Emil tervei. MÉM (1914) 3. 31.

${ }^{166}$ MÉM (1914) 3. 1.

${ }^{167}$ I. díj: Hikisch Rezső, II. díj: Reisner Imre, III. díj: Balogh Lóránd. MÉM (1916) 7-8. 1.

${ }^{168}$ Mint például a Tőzsdepalota és a Pesti Kereskedelmi Bank (Alpár Ignác), a Kolozsvári Egyetemi Könyvtár (Giergl Kálmán - Korb Flóris), Kossuth Lajos mauzóleuma (Gerster Kálmán), vagy a Belvárosi Takarékpénztár (Schmahl Henrik).

${ }^{169}$ Magyar Vilmos szerkesztésében külön album formában kiadták a Nemzeti Színház pályaterveinek gyüjteményét. ÉPIP (1913) 33. 
A pályázatok létjogosultsága megkérdőjelezhetetlenné vált, eljárásrendje pedig megszilárdult. A visszatérő botrányok ellenére az építészeti tervpályázat hazánkban mint intézmény és mint kulturális jelenség - nagy lépést tett elöre. Számos esetben bizonyíthatóan sikerült közelebb kerülni a modern pályázat eszmeiségéhez, amelyben nem pusztán a feladatnak leginkább megfelelő terv/tervező és a legmegépíthetőbb terv kiválasztása a cél, hanem az eredmény minél szélesebb körü nyilvánossága és a később hasznosítható tanulságok levonása, közzététele - és ezáltal az építészet fejlődésének segítése.

\section{IRODALOM}

Ács Piroska: Az Iparmüvészeti Múzeum palotájának épitéstörténete. Iparművészeti Múzeum, Budapest 1996.

Baku Eszter - Csernus Éva: A Magyar Építőművészek Szövetségének története 1902-1948 között. Épités - Épitészettudomány 40 (2012) 1. 113-134.

Bauer Henrik: Építészeti tervversenyek. MMÉEK (1891) 52.

Bibó István: Pollack Mihály Országháza-terve. Müvészettörténeti Értesitö 22 (1973) 22-36.

Borsa Miklós - Tolnay Pál: Az ismeretlen Operaház. Müszaki Kiadó, Budapest 1984.

Chamostra, Walter M.: Wettbewerbsordnung Architektur. BIK-Verlags-Ges.m.b.H, Wien 2010.

Czétényi Piroska - Szvoboda Gabriella: Az Operaház. Képzőművészeti Kiadó, Budapest 1987.

Estók János: A városligeti Vajdahunyadvár. Kreatéka Kft., Budapest 2007.

Gábor Eszter: A lipótvárosi zsinagóga pályázata - Meg nem épült Budapest. Budapesti Negyed 6 (1998) 1. 5-47.

Gáll Imre: A budapesti Duna-hidak. Müszaki Kiadó, Budapest 1984.

Gerle János: Az 1912-13-as Nemzeti Színház pályázatról. Magyar Építőmüvészet 34 (1985) 4. 53-55.

Gerle János: Századfordulós stílusirányzatok. In: Magyarország épitészetének története. Szerk.: Sisa József - Dora Wiebenson. Vince Kiadó, Budapest 1998.

Hajnóczi Gábor: Nemzeti építészetünk stíluskérdései az Akadémia székházára kiírt pályázat körüli vitában. Épités- Épitészettudomány 17 (1985) 1-2. 81-98.

Hajós György: Buda-Pest város rendezési tervpályázata 1871-ből. In: Évfordulóink a müszaki és természettudományokban. 1996. 117-120.

Kalmár Miklós: Az épitészet története. Historizmus Századforduló. Nemzeti Tankönyvkiadó, Budapest 2001.

Kelecsényi Kristóf - Torma Ágnes: Schmahl Henrik (1846-1912), egy német kőműveslegény felemelkedése a dualizmus kori Budapesten. In: Épitőmüvészek Ybl és Lechner korában. Szerk.: Rozsnyai József. Terc Kiadó, Budapest 2015.

Kemény Mária: A Magyar Tudományos Akadémia palotája. Osiris Kiadó, Budapest 2015.

Komárik Dénes: Az 1844-es Pesti Országháza tervpályázat. Tanulmányok Budapest Múltjából 19 (1972) 251-281.

Komárik Dénes: Az 1861-es ideiglenes országháza tervpályázat. In: Az ország háza. Buda-pesti országháza tervek 1784-1884. Szerk.: Gábor Eszter - Verő Mária. Szépmúvészeti Múzeum, Budapest 2000. 105-125.

Lakatos Mihály - Mészáros L. Edgár - Óriás Zoltán (szerk.): Az 50 éves Vállalkozók Lapja jubileumi albuma. A magyar épitómüvészet és épitöipar 50 éve. Vállalkozók Lapja, Budapest 1930.

Mace, Angela: Architecture in manuscript, 1601-1996. A Guide to the British Library Manuscripts and Archives Collection. Mansell 1998.

Marótzy Katalin: 150 éve született Alpár Ignác. Architectura Hungariae 8 (2005) 1.

Marótzy Katalin: Wéber Antal építészete a magyar historizmusban. Terc Kiadó, Budapest 2009. 
Marótzy Katalin: Ybl Miklós és az építészeti közélet - pályázatok a Magyar Mérnök- és Építészegyletben. Ars Hungarica 40 (2014) 4. 489-496.

Mattie, Erik - De Jong, Ceres (edit): Architectural competitions 1792-today. Benedikt Taschen, Köln 1994.

Németh Nóra - Marótzy Katalin: A századforduló két legfontosabb építészeti pályázata, és sajtója I. Architectura Hungariae 10 (2011) 4.

Németh Nóra - Marótzy Katalin: A századforduló két legfontosabb építészeti pályázata, és sajtója II. Architectura Hungariae 10 (2011) 4.

Németh Nóra - Marótzy Katalin: Stíluskérdések a századfordulón - Két építészeti pályázat háttere. Épités - Épitészettudomány 41 (2013) 3-4. 253-270.

Rosch Gábor: Alpár Ignác épitészete. Enciklopédia Kiadó, Budapest 2005.

Sisa József: Steindl Imre. Holnap Kiadó, Budapest 2005.

Sterk János (szerk.): Magyar Építőmüvészeti Pályázatok. Kosmos müintézet, Budapest 1894/95.

Vadas Ferenc: Tudományos dokumentáció. New York palota és kávéház. 1995. (Forster Központ, Tervtár 1tsz. 46110.)

Vadas Ferenc: Épitészettörténeti tudományos dokumentáció a Szentháromság téri volt pénzügyminisztérium épületéröl. 1998.

Verő Mária - Gábor Eszter (szerk.): Az ország háza: Buda-Pesti Országháza-tervek 1784-1884. Szépmüvészeti Múzeum, Budapest 2000.

\section{THE DESIGN COMPETITION AS A PHENOMENON IN HUNGARIAN LATE HISTORICIST ARCHITECTURE}

\section{Summary}

The history of the design competitions in Hungary started in the middle of the $19^{\text {th }}$ century, and it evolved until the First World War. The significant competitions around 1867 have been already researched but only some of the events during the age of late historicism have been analyzed so far. The purpose of our paper is to summarize the history of the design competitions from Miklos Ybl's death to the First Word War. The primary resource of our research was the architectural press of the period. We collected the competition-related news and articles between 1890 and 1920 to demonstrate the tendencies and to analyze the major competitions of the era. In the first years of the $20^{\text {th }}$ century reproduction technologies were rapidly developing, therefore we know a great amount of unbuilt proposal plans. These documents can make our knowledge more detailed about the turn of the century architecture besides the built plans and edifices. The first advocacy organization of architects in Hungary was the Association of Hungarian Engineers and Architects. From its foundation in 1867 until the dissolution in 1944 this association was always very much concerned about the matter of the open architectural design competitions. There are several documents subscribed by them that are very conducive to study, in order to understand the architectural thinking of the period.

Keywords: Historicism, late Historicism, design competition, architectural competition, turn of the century, second half of $19^{\text {th }}$ century, Association of Hungarian Engineers and Architects 